Egyptian Poultry Science Journal

http://www.epsaegypt.com

ISSN: 1110-5623 (Print) - 2090-0570 (On line)

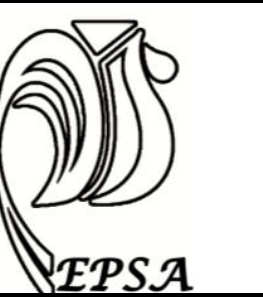

\title{
EFFECT OF SALINITY LEVEL AND VITAMINS IN DRINKING WATER ON PRODUCTIVE PERFORMANCE AND SOME BLOOD CONSTITUENTS OF BROILER CHICKS
}

\author{
H.A. Hassan \\ Anim. Prod. Dep., Fac. of Agric., South Valley Univ., Egypt \\ Corresponding Author: Dr. Hamdy Hassan, Email: hamde_202@yahoo.com
}

\begin{abstract}
Received: 20/07/2016
Accepted: 17/08/2016

ABSTRACT: The experiment reported herein aimed to investigate whether sodium chloride $(\mathrm{NaCl})$ provided through drinking water affected the body weight $(\mathrm{BW})$, body weight gain (BWG), water intake (WI), feed intake (FI), feed conversion (FCR), carcass weight $(\mathrm{CW})$ and dressing percentage of broiler chickens. In a complete randomized block experimental design, a total of 120 one-day-old Ross broiler chicks were allocated randomly into 4 treatment groups. Each treatment group consisted of three replicates of 10 birds each. The birds were offered ad libitum water and basal diets the composition of which was 23 and $21 \%$ crude protein and 3010 and $3160 \mathrm{kcal} \mathrm{ME/kg} \mathrm{during} \mathrm{starter} \mathrm{and}$ growing periods respectively. Treatments were drinking tap water (tap water; control group), $1500 \mathrm{ppm} \mathrm{NaCl}$ in drinking water (T1, salt stress group), $1500 \mathrm{ppm} \mathrm{NaCl}$ plus 100 IU/kg of feed DL- $\alpha$-tocopherol (T2, $1500 \mathrm{ppm} \mathrm{VE)} \mathrm{and} 1500 \mathrm{ppm} \mathrm{NaCl}$ plus $500 \mathrm{IU} / \mathrm{L}$ of water L-ascorbic acid (T3, $1500 \mathrm{ppm} \mathrm{VC).} \mathrm{At} \mathrm{the} \mathrm{end} \mathrm{of} \mathrm{the} \mathrm{experimental} \mathrm{period,} \mathrm{no}$ significant differences among the groups in terms of BW and BWG. Moreover, adding Vitamin $\mathrm{E}$ or $\mathrm{C}$ recorded the lowest $\mathrm{BW}$ and $\mathrm{BWG}$. While, birds received salt supplemented with vitamin $\mathrm{C}$ recorded the highest WI and FI during experimental periods. Relative weights of edible organs for birds treated with $1500 \mathrm{mg} / \mathrm{L} \mathrm{NaCl}$ plus $100 \mathrm{IU} / \mathrm{kg}$ of feed DL- $\alpha$-tocopherol were increased significantly $(\mathrm{P}<0.01)$ compared with other experimental groups except heart. Additionally, there were a significant decrease $(\mathrm{P}<0.01)$ in $\mathrm{Ca}, \mathrm{Mg}$, and $\mathrm{P}$ of birds received Vita $\mathrm{E}$ or $\mathrm{C}$ compared to other treatments. While, there was no significant differences among treatments in $\mathrm{K}$ concentration. Furthermore, Aldosterone concentration was increased with vita $\mathrm{C}$ addition compared with other treatments. These results indicate that productive and physiological performance of broiler chicks was not adversely affected by $1500 \mathrm{ppm} \mathrm{NaCl}$ in drinking water
\end{abstract}

Key words: sodium chloride, broiler, L-ascorbic acid, DL- $\alpha$-tocopherol, blood constituents 


\section{INTRODUCTION}

Over large areas of the arid or semi-arid regions of Africa, Asia, America, and Australia millions of livestock subsist for many months of the year upon water supplies of high saline content. Underground waters drawn from wells or bores in these regions are frequently high saline, the principle salts being the chlorides, sulphates, or bicarbonates of sodium, with sodium chloride usually predominating.

The poultry farm must be managed to provide clean and cool water to all birds at all time (Lesson and Summers, 1997), while the nutritional importance of minerals in the diets has been examined extensively, the role of minerals in drinking water has received much less this attention. is surprising since underground water supplies are a common source of drinking water for poultry in many countries and such water often contains high concentration of dissolved mineral salts.

Excess minerals in feed or water above the nutritional requirement will cause increased water consumption and may result in wet manure.

.Watkins et al., (2005) reported that the level of $\mathrm{Na}$ and $\mathrm{Cl}$ in drinking water and in the diet significantly affected live performance in broiler, with significant interaction between dietary and water levels. Likewise,

water intake is a determinant of broiler performance, as it influences bird health and welfare status (Soares et al., 2007). Thus, water availability is essential to achieve efficient broiler production. However, there are many factors that may influence water intake by the birds, such as the intake of feed and minerals (Leeson and Summers, 1997). Moreover the amount of water intake is important, as it has a direct influence on feed intake (Viola et al., 2009; Soares et al., 2007). Considering the high metabolic rate of modern commercial broilers strains, water can be one of the means used by the birds for thermoregulation (Marks, 1985), and therefore it should be provided continuously to allow full development of the birds.

Drinking water itself contains $\mathrm{NaCl}$ at various concentrations. Therefore, when water is used in poultry feeding, the $\mathrm{NaCl}$ content of the water should be measured to ensure that an appropriate amount of $\mathrm{NaCl}$ is provided. Khalafalla et al. (1998) have reviewed the responses of newly hatched poultry (layer type and broiler chickens, turkey poults and ducklings) to mineral supplements in drinking water. These authors noted that salt levels in drinking water ranged from 2.6 to $10.6 \mathrm{~g} / \mathrm{l}$ and showed that high concentrations of salt in drinking water were associated with reduced growth and increased mortality in newly hatched poultry. On the other hand, Afifi et al. (1992) noted that the main cause of high mortality is the toxic effect of $\mathrm{NaCl}$ when used at high levels in feeds or water. The authors noted also that broiler chicks could tolerate up to $2 \mathrm{~g} \mathrm{NaCl} / 100 \mathrm{ml}$ in the drinking water, and live weight gains are decreased, water consumption and water to feed ratio are increased, and feed conversion ratio (g feed/g gain) is adversely affected beyond the $0.2 \%$ level.

Vitamin E has been reported as an excellent biological chain-breaking antioxidant that protects cells and tissue from lipoperoxidative damage induced by free radicals. Vitamin $\mathrm{C}$ limits the metabolic signs of stress and alleviates the physiological consequences of stress, resulting in improved performance, immunological competence and behavior of chickens. The antioxidative property of vitamin $\mathrm{E}$ in chickens is suggested to have significant role in the development of immune response through protection of the cells, such as lymphocytes, macrophages, and plasma cells from oxidative damage, 
and enhances the function and proliferation of these cells to face the oxidative stress (Franchini, et al 1991 and Meydani and Blumberg, 1993).

Shanawany et al. (1989) examined the effect of $\mathrm{NaCl}$ in drinking water on Japanese quails. The authors used concentrations of $0,500,1000$ or $1500 \mathrm{mg}$ $\mathrm{NaCl} / \mathrm{l}$ in the drinking water and noted that water intake increases and feed consumption decreases as salt concentration increases. Damron, (1998) added up to $800 \mathrm{ppm} \mathrm{NaCl}$ to the drinking water of White Leghorn hens and detected that daily feed and water intake and body weight change over the experimental period were not influenced by any level of waterborne $\mathrm{NaCl}$. Balnave (1988) observed improvements in growth when three-to-sixweek-old broilers were provided with up to $2.4 \mathrm{~g} \mathrm{NaCl} / 1$ of drinking water. Balnave (1989) and Khalafalla et al. (1998) reported that the toxicity of sodium chloride given in the drinking water was approximately the same as an equivalent intake from the diet. These authors also noted that a supplement of $3 \mathrm{~g} \mathrm{NaCl} / \mathrm{l}$ to the drinking water was not toxic to two-day old chicks. Therefore, relatively low concentrations of sodium chloride in drinking water may improve live weight gain in broilers, perhaps through a greater retention of water. The result of previous works on the tolerance of poultry to saline waters has apparently not been studied but there were less information on tolerance of broilers chickens to high salt with vitamins. Therefore the objectives of this study are to evaluate the effect of $\mathrm{NaCl}$ in the drinking water of this chicks on feed intake, growth rate, feed conversion ratio and water consumption of broiler chicks using water supplemented with or without Vita E or Vita C.

\section{MATERIALS AND METHODS}

Birds managements and Experimental design :The present experiment was carried out at the Experimental Poultry Farm,
Department of Animal and Poultry production, Faculty of Agriculture, University of South Valley, during the period from 5 January, to 17 February, 2015. It was designed to determine the effect of Sodium Chloride $(\mathrm{NaCl})$ addition in drinking water on the growth performance, carcass traits and some blood parameters in Ross broiler chicks. One hundred and twenty, one day-old Ross broiler chickens were wing-banded, individually weighed, and randomly assigned to four experimental groups, (control and 3 treatments). Each group included three replicates, each of 10 chicks. Birds in the $\mathrm{T} 1$, which served as the control, were drinking tap water, Birds in T 2 were drinking tap water supplied with $1500 \mathrm{ppm} \mathrm{NaCl}$ (salt stress group). Birds in the $\mathrm{T}$ 3. drinking tap water Add to 1500 ppm $\mathrm{NaCl}$ plus $100 \mathrm{IU} / \mathrm{kg}$ of diet DL- $\alpha$ tocopherol $\mathrm{T}$ 4. drinking tap water Add to1500 ppm $\mathrm{NaCl}$ plus $500 \mathrm{IU} / \mathrm{L}$ of water L-ascorbic acid (T3). The light intensity was 15 Lux during the first three days and 5 Lux thereafter. Chicks were housed and raised in two tiers-wire floor, batteries with cages (width: $97 \mathrm{~cm}$; length: $50 \mathrm{~cm}$; height: $45 \mathrm{~cm}$ ), located in a closed broiler house under controlled managerial and hygienic conditions. The interior temperature which started by about $32{ }^{\circ} \mathrm{C}$ during the first week, was reduced by about $2{ }^{\circ} \mathrm{C}$ every week to reach $24{ }^{\circ} \mathrm{C}$ at the fourth week of age and remained constant in the presence of a relative humidity ranging between 55$60 \%$ up to the end of the experiment. The temperature values and the relative humidity percentages were daily recorded by using a thermo-hygrograph and the temperature humidity indices-THI values were calculated allover the experimental period. The birds were fed on starter and grower diets from 1 to 21 and 22 to 42 days of age, respectively and the feed and water were available all the time.

\section{Growth performance :}

Birds per each replicate were weekly weighed on individual basis. The body 
weight gain BWG was calculated as the difference between final and the initial body weight. The average feed intake FI per each replicate was weekly calculated as the difference between the offered and remained amounts of feed. The mean feed conversion ratio FCR was weekly calculated by dividing total feed consumed by the total body weight gain of birds per each replicate.

\section{Carcass criteria:}

At the end of the experiment at 42 days of age, 18 fasted chicks, (for 8 hours), per each group i.e. three around the average weight / each replicate were slaughtered. After complete bleeding, they were scalded and mechanically plucked. The edible organs (heart, liver, empty gizzard and spleen) as well as the abdominal fat were gently removed, weighed and calculated as percentages of carcass weight. The dressing percentage was calculated, by dividing the carcass and giblets weights by the preslaughter live body weight of birds. Also, the lengths of intestines and Ceca were recorded.

\section{Blood parameters:}

Representative blood samples were collected from 9 hens randomly chosen from each treatment (3 from each replicate) at the end of the experiment and centrifuged. Serum was collected and stored at $-20^{\circ} \mathrm{C}$ for determination of Potassium (K) ,calcium (Ca). magnesium $(\mathrm{Mg})$, sodium $(\mathrm{Na})$, phosphorus $(\mathrm{P})$ and Aldosterone.

Statistical analyses:

Data were statistically analyzed by ANOVA, using the General Linear Model (GLM) Procedure of SAS software (SAS institute, version 9.1, 2005). Duncan's multiple range test (Duncan, 1955) was used to detect the differences among means of different groups.

\section{RESULTS}

Data reported in Table 2, shows that, salt stress without or with vitamins supplementation decreased broiler BW at 3 weeks of age comparing with control group. Whereas, there were no significant differences among control, salt and salt supplemented with vita $C$ at 6 weeks of age. Moreover, birds received salt supplemented with vita $\mathrm{E}$ recorded the lowest BW compared with control group. As well as, BWG had the same trend as BW at 0-3 weeks of age. While, at 3-6 weeks of age BWG increased with salt stress compared with other groups. Moreover, there were no significant differences between control and salt stress at 0-6. Contrary, WI decreased at 0-3, 3-6 and $0-6$ weeks of age compare with other groups. While, birds received salt supplemented with vita $\mathrm{C}$ recorded the highest WI and FI during experimental periods. Birds received vitamins $\mathrm{E}$ or $\mathrm{C}$ recorded the worst $\mathrm{FC}$ during the experimental periods.

\section{Carcass measurements:,}

The results presented in Table, 3 indicated the effect of treatments on dressed carcass, abdominal fat and relative weights of some edible organs such as gizzard, liver, heart, and spleen. Salt stress with or without vitamin addition increased dressed carcass and abdominal fat compared with control birds. Relative weights of edible organs for birds treated with $1500 \mathrm{mg} / \mathrm{L} \mathrm{NaCl}$ plus $100 \mathrm{IU} / \mathrm{kg}$ of feed DL- $\alpha$-tocopherol were increased significantly $(\mathrm{P}<0.01)$ compared with other experimental groups except heart. Additionally, it was observed that, birds received $500 \mathrm{IU} / \mathrm{L}$ of water Lascorbic acid to broiler diet significantly $(\mathrm{P}<0.01)$ increased length of intestines and ceca compared with those fed $100 \mathrm{IU} / \mathrm{kg}$ of feed DL- $\alpha$-tocopherol.

\section{Blood parameters:}

Concerning serum concentration of $\mathrm{K}, \mathrm{Ca}$, $\mathrm{Mg}, \mathrm{Na}, \mathrm{P}$ and Aldosterone at the end of the experiment period are shown (Fig. 1 and 2). It was found a significant decrease $(\mathrm{P}<0.01)$ in $\mathrm{Mg}$, and $\mathrm{P}$ of birds fed diets supplemented with Vita E and C compared with salt stress group (T1); while salt stress treatment (T1), T2 and T3 decreased $\mathrm{Ca}$ 
concentration compared with control group. Moreover, $\mathrm{Na}$ level increased $(\mathrm{P}<0.05)$ significantly in salt stress groups $\mathrm{T} 1$ and $\mathrm{T} 3$ while, birds, received $\mathrm{T} 2 \mathrm{Na}$ level decreased significantly compared with other groups. Additionally, there were no significant differences among treatments in $\mathrm{K}$ concentration. Furthermore, aldosterone concentration was increased with vita $\mathrm{C}$ addition compared with other treatments.

\section{DISCUSSION}

Sodium and $\mathrm{Cl}$ are minerals with important physiological functions. Optimum dietary balance of these minerals allows better chicken performance and may reduce leg problems. Sodium is an essential element for animals; the body contains approximately $0.2 \%$ of sodium. About one - quarterof this amount is localized in the skeleton in an insoluble rather inert form, but the balance was found in the extra cellular fluids where it undergoes a very active metabolism. The element makes up $93 \%$ of the bases of the blood serum, and thus it was the predominant basic element concerned in neutrality regulation. Sodium seems to be absent from blood cells, but it does occur in considerable amount in the muscles, where it is associated in some unknown way with their contraction . A lack of the elements also lowers the utilization of digested protein and energy and prevents reproduction.

Chloride is differing from sodium, it is found in large concentrations both within and outside of the cells of the body tissues. Blood cells contain about one - half as much as the plasma, approximately 15 to $20 \%$ of the chlorides of the bloods, principally sodium chloride, make up two thirds of its acidic ions. This indicates their large role in acid - base regulation. The gastric secretion contains chlorines as free acid and in the form of salts. The body has a certain capacity to store chlorine in the skin and subcutaneous tissues. Its excretion follows that of sodium, the body requirement is approximately half of that for sodium.
The requirement of these 2 ions varied from 0.15 to $0.40 \%$ for $\mathrm{Na}+$ and 0.15 to $0.30 \%$ for $\mathrm{Cl}-$ (NRC, 1994; OviedoRondø’n et al., 2001; Murakami et al., 2001). Excessive dietary $\mathrm{Na}+$ causes physiological responses such as increased water consumption, manure moisture, and urinary excretion and significantly decreases kidney glomerular filtration ratio, which is regulated by variation in the arginine-vasotocin secretion (Vena et al., 1990). Therefore, it is necessary to provide the $\mathrm{Na}+$ and $\mathrm{Cl}-$ in proper amounts to ensure minimum secretions through kidney. The results of the present study indicated that $1500 \mathrm{ppm} \mathrm{NaCl}$ in the drinking water had no adverse effects on chick's performance, caused no effect in feed intake compared with the control group. These results are similar to the results obtained by (Watkins et al., 2005). He found that in dietary $\mathrm{NaCl}$ level based on the amount of $\mathrm{Na}$ in the drinking water of combination of $500 \mathrm{mg} \mathrm{Na} / \mathrm{L}$ in the water did not affect the feed intake. Total body weight gain was not affected by the treatment also was not affected by the different levels of $\mathrm{NaCl}$ in drinking water during the experimental period. These findings were in line with results obtained by (Ross 1979). However the results were found in the absence of dietary $\mathrm{Na}$ addition of $1500 \mathrm{ppm}$ of $\mathrm{Na}$ to the drinking water significantly improved growth and feed efficiency. The variation may be due to the concentrations of mineral salt which significantly impaired performance are considerably higher than the concentrations normally found in drinking water including underground sources. In our study, the final body weight and body weight gain of broiler receiving $1500 \mathrm{ppm} \mathrm{NaCl} / \mathrm{l}$ in the drinking water were numerically higher than those receiving $1500 \mathrm{ppm} \mathrm{NaCl} / \mathrm{l}$ supplemented with vita $\mathrm{E}$.

Gene et al. (1999) reported that, feed conversion ratio was not affected by the treatment during the experimental period except on week one and two with different 
dietary sodium levels $(0.1 \%-0.3 \%-0.7 \%$ - $0.9 \% \mathrm{NaCl}$ ) show that about $0.4 \%$ added sodium chloride is necessary to achieve maximum fed conversion ratio. The variation in the results may be due to high level of $\mathrm{NaCl}$ for dietary source and the water source.

Water intake significantly differ with our treatments in contrast with Austic (1985) who indicated that, weekly water consumption was not affected by the different levels of $\mathrm{NaCl}$ in the experiment, except on week two . These findings agree with those reported by (??? Author ?) $\mathrm{NaCl}$ supplemen where ts of up to $2 \mathrm{~g} / 1$ of drinking water or $4 \mathrm{~g} / \mathrm{kg}$ of diet were given between (one and six weeks of age to broiler) chick receiving commercial diet containing $2.5 \mathrm{~g} \quad \mathrm{NaCl} \quad / \mathrm{Kg}$ observed increase in the intakes of drinking water up to $15 \%$ the variation may be due to environmental conditions of the study or they may include the palatability of the diet or any changes in water supply under hot climatic conditions.

Our results indicated that blood minerals significantly affected with salt stress with or without vitamin addition and this may be due to aldosterone mechanism of action. Aldosterone is a steroid hormone (mineralocorticoids) produced by the outer section (zona glomerulosa) of the adrenal cortex in the adrenal gland. It plays a central role in the regulation of blood pressure mainly by acting on the distal tubules and collecting ducts of the nephron, increasing reabsorption of ions and water in the kidney, to cause the conservation of sodium, secretion of potassium, increase in water retention, and increase in blood pressure and blood volume. Aldosterone tends to promote $\mathrm{Na}+$ and water retention, and lower plasma $\mathrm{K}+$ concentration by the following mechanisms: Acting on the nuclear mineralocorticoid receptors (MR) within the principal cells of the distal tubule and the collecting duct of the kidney nephron, it upregulates and activates the basolateral $\mathrm{Na}+/ \mathrm{K}+$ pumps, which pumps three sodium ions out of the cell, into the interstitial fluid and two potassium ions into the cell from the interstitial fluid. This creates a concentration gradient which results in reabsorption of sodium $(\mathrm{Na}+)$ ions and water (which follows sodium) into the blood, and secreting potassium $(\mathrm{K}+)$ ions into the urine (lumen of collecting duct) Changlong et al., (2012). Lawrence and Gustavo (2000) said that, Aldosterone has been implicated in the regulation of both $\mathrm{Na}$ and $\mathrm{K}$ concentrations in the plasma. Release of the hormone is known to be stimulated by high plasma $\mathrm{K}$, and infusion of aldosterone lowers plasma $\mathrm{K}$. However, the correlation between changes in mineralocorticoid levels and rates of $\mathrm{K}$ secretion is not perfect, suggesting that other factors may be involved.

\section{CONCLUSIONS}

It could be stated that growth and physiological performance of broiler chicks was not adversely affected by 1500 ppm $\mathrm{NaCl}$ in drinking water 
Table (1): Composition and calculated analysis of experimental diets

\begin{tabular}{|l|c|c|}
\hline \multicolumn{1}{|c|}{ Ingredients } & Starter diet & Grower diet \\
\hline Yellow corn & 62.18 & 67.00 \\
Soybean meal (44\% CP) & 27 & 20.30 \\
Corn gluten meal (60\% CP) & 6.52 & 8.00 \\
Di-Calcium Phosphate & 1.92 & 1.9 \\
Limestone & 1.29 & 1.37 \\
Salt (NaCl) & 0.12 & 0.10 \\
DL-Methionine & 0.14 & 0.24 \\
L-Lysine & 0.19 & 0.48 \\
Vit. \& Min. Premix ${ }^{1}$ & 0.25 & 0.24 \\
Filler (sand) & 0.01 & 0.37 \\
Total & 100.00 & 100.00 \\
Calculated Analysis, \% & & \\
& 3010 & 3160 \\
ME (kcal/ kg) & & \\
Crude Protein & 23 & 21 \\
Calcium & 1.00 & 1.00 \\
Available Phosphorus & 0.50 & 0.50 \\
Lysine & 1.16 & 1.28 \\
Methionine & 0.52 & 0.59 \\
Choline (mg/ kg) & 0.13 & 0.15 \\
\hline
\end{tabular}

1Premix provides by kg: Vit A, 5500 IU; Vit E, 11 IU; Vit D3, 1100 IU; riboflavin, $4.4 \mathrm{mg}$; Ca pantothenate, $12 \mathrm{mg}$; nicotinic acid, $44 \mathrm{mg}$; choline chloride, $191 \mathrm{mg}$; vitamin B12, $12.1 \mathrm{ug}$; vitamin B6, 2.2mg; thiamine ( as thiamine mononitrate), 2.2 $\mathrm{mg}$; folic acid, $0.55 \mathrm{mg}$ and d- biotin, $0.11 \mathrm{mg}$. Trace mineral (mg $/ \mathrm{kg}$ diet): Mn, 60; $\mathrm{Zn}, 50 ; \mathrm{Fe}, 30 ; \mathrm{Cu}, 5$ and $\mathrm{Se}, 0.3$. 
Table (2): Productive performance of broiler chicks as affected by treatments

\begin{tabular}{|c|c|c|c|c|c|c|}
\hline & \multicolumn{4}{|c|}{ Treatments } & \multirow[b]{2}{*}{ SEM } & \multirow[b]{2}{*}{ P. value } \\
\hline & Control & $\begin{array}{l}1500 \\
\text { ppm }\end{array}$ & $\begin{array}{c}1500 \\
\text { ppm VE }\end{array}$ & $\begin{array}{c}1500 \\
\text { ppm VC }\end{array}$ & & \\
\hline $\begin{array}{l}\text { Dressed carcass } \\
\text { (including giblets) }(\%)\end{array}$ & $79.47^{\mathrm{ab}}$ & $81.76^{\mathrm{a}}$ & $81.19^{\mathrm{ab}}$ & $78.90^{\mathrm{c}}$ & 0.43 & 0.0190 \\
\hline Abdominal fat (\%) & $0.76^{\mathrm{d}}$ & $1.45^{\mathrm{a}}$ & $0.98^{c}$ & $1.32^{\mathrm{b}}$ & 0.08 & 0.0001 \\
\hline Blood (\%) & $3.82^{\mathrm{b}}$ & $3.85^{\mathrm{b}}$ & $4.95^{\mathrm{a}}$ & $3.37^{\mathrm{c}}$ & 0.18 & 0.0001 \\
\hline Body organ weights (\%) & & & & & & \\
\hline Gizzard & $1.38^{\mathrm{c}}$ & $1.46^{\mathrm{bc}}$ & $1.62^{\mathrm{a}}$ & $1.52^{\mathrm{ab}}$ & 0.03 & 0.0038 \\
\hline Liver & $2.75^{\mathrm{bc}}$ & $2.63^{\mathrm{c}}$ & $3.17^{\mathrm{a}}$ & $2.83^{\mathrm{b}}$ & 0.06 & 0.0001 \\
\hline Heart & 0.61 & 0.57 & 0.59 & 0.58 & 0.01 & 0.0557 \\
\hline Spleen & $0.18^{\mathrm{c}}$ & $0.24^{\mathrm{b}}$ & $0.31^{\mathrm{a}}$ & $0.23^{\mathrm{b}}$ & 0.01 & 0.0001 \\
\hline $\begin{array}{l}\text { Body organs length } \\
(\mathrm{cm})\end{array}$ & & & & & & \\
\hline Intestines & $227.67^{\mathrm{a}}$ & $210.67^{b}$ & $190.00^{\mathrm{d}}$ & $202.33^{c}$ & 4.15 & 0.0001 \\
\hline Ceca & $40.33^{\mathrm{a}}$ & $35.67^{\mathrm{c}}$ & $38.00^{\mathrm{b}}$ & $40.33^{\mathrm{a}}$ & 0.61 & 0.0001 \\
\hline
\end{tabular}

Means a, b, c, in the same row without common superscripts are significantly different $(\mathrm{P}<0.05)$ 
Table (3): Slaughter traits of broiler chicks as affected by treatments

\begin{tabular}{|c|c|c|c|c|c|c|}
\hline \multirow[b]{2}{*}{ Items } & \multicolumn{4}{|c|}{ Treatments } & \multirow[b]{2}{*}{ SEM } & \multirow[b]{2}{*}{ P. value } \\
\hline & $\begin{array}{c}\text { Control } \\
\text { (T1) }\end{array}$ & $\begin{array}{c}1500 \\
\operatorname{ppm}(\mathrm{T} 2)\end{array}$ & $\begin{array}{c}1500 \text { ppm } \\
\text { VE(T3) }\end{array}$ & $\begin{array}{c}1500 \mathrm{ppm} \\
\text { VC(T4) }\end{array}$ & & \\
\hline \multicolumn{7}{|c|}{ Body weight, $\mathrm{g}$} \\
\hline $3 \mathrm{WK}$ & $852.00^{\mathrm{a}}$ & $820.33^{c}$ & $815.50^{c}$ & $833.33^{b}$ & 4.43 & 0.0001 \\
\hline $6 \mathrm{WK}$ & $2466.11^{\mathrm{a}}$ & $2473.33^{\mathrm{a}}$ & $2319.89^{b}$ & $2343.33^{\mathrm{ab}}$ & 26.91 & 0.0480 \\
\hline \multicolumn{7}{|c|}{ Body weight gain, g/bird/day } \\
\hline $0-3 \mathrm{WK}$ & $38.42^{\mathrm{a}}$ & $36.84^{\mathrm{b}}$ & $36.63^{\mathrm{b}}$ & $37.49^{\mathrm{ab}}$ & 0.27 & 0.0480 \\
\hline $3-6 \mathrm{WK}$ & $76.86^{\mathrm{b}}$ & $78.71^{\mathrm{a}}$ & $71.97^{\mathrm{c}}$ & $71.90^{\mathrm{c}}$ & 0.91 & 0.0421 \\
\hline $0-6 \mathrm{WK}$ & $57.64^{\mathrm{a}}$ & $57.78^{\mathrm{a}}$ & $54.13^{\mathrm{b}}$ & $54.70^{\mathrm{b}}$ & 0.53 & 0.0001 \\
\hline \multicolumn{7}{|c|}{ Water intake/bird/day } \\
\hline $0-3 \mathrm{WK}$ & $125.02^{\mathrm{a}}$ & $120.92^{b}$ & $126.06^{\mathrm{a}}$ & $127.28^{\mathrm{a}}$ & 0.813 & 0.0029 \\
\hline $3-6 \mathrm{WK}$ & $279.70^{\mathrm{b}}$ & $243.77^{c}$ & $281.47^{\mathrm{b}}$ & $285.42^{\mathrm{a}}$ & 0.912 & 0.0001 \\
\hline $0-6 \mathrm{WK}$ & $254.33^{\mathrm{b}}$ & $228.98^{c}$ & $256.09^{\mathrm{ab}}$ & $259.35^{\mathrm{a}}$ & 1.26 & 0.0001 \\
\hline \multicolumn{7}{|c|}{ Feed intake, g/bird/day } \\
\hline $0-3 \mathrm{WK}$ & $70.24^{\mathrm{a}}$ & $67.94^{\mathrm{b}}$ & $70.83^{\mathrm{a}}$ & $71.51^{\mathrm{a}}$ & 0.45 & 0.0003 \\
\hline $3-6 \mathrm{WK}$ & $142.71^{b}$ & $124.38^{\mathrm{c}}$ & $143.61^{b}$ & $145.63^{\mathrm{a}}$ & 2.59 & 0.0029 \\
\hline $0-6 \mathrm{WK}$ & $116.67^{\mathrm{b}}$ & $105.04^{c}$ & $117.48^{\mathrm{ab}}$ & $118.97^{\mathrm{a}}$ & 1.69 & 0.0001 \\
\hline \multicolumn{7}{|c|}{ Feed conversion ratio } \\
\hline $0-3 \mathrm{WK}$ & $1.828^{b}$ & $1.844 \mathrm{a}^{\mathrm{b}}$ & $1.934^{\mathrm{a}}$ & $1.910^{\mathrm{ab}}$ & 0.018 & 0.1043 \\
\hline $3-6 \mathrm{WK}$ & $1.868^{\mathrm{b}}$ & $1.581^{\mathrm{c}}$ & $2.013^{\mathrm{a}}$ & $2.041^{\mathrm{a}}$ & 0.056 & 0.0001 \\
\hline $0-6 \mathrm{WK}$ & $2.058^{\mathrm{b}}$ & $1.818^{\mathrm{c}}$ & $2.172^{\mathrm{a}}$ & $2.180^{\mathrm{a}}$ & 0.045 & 0.0001 \\
\hline
\end{tabular}



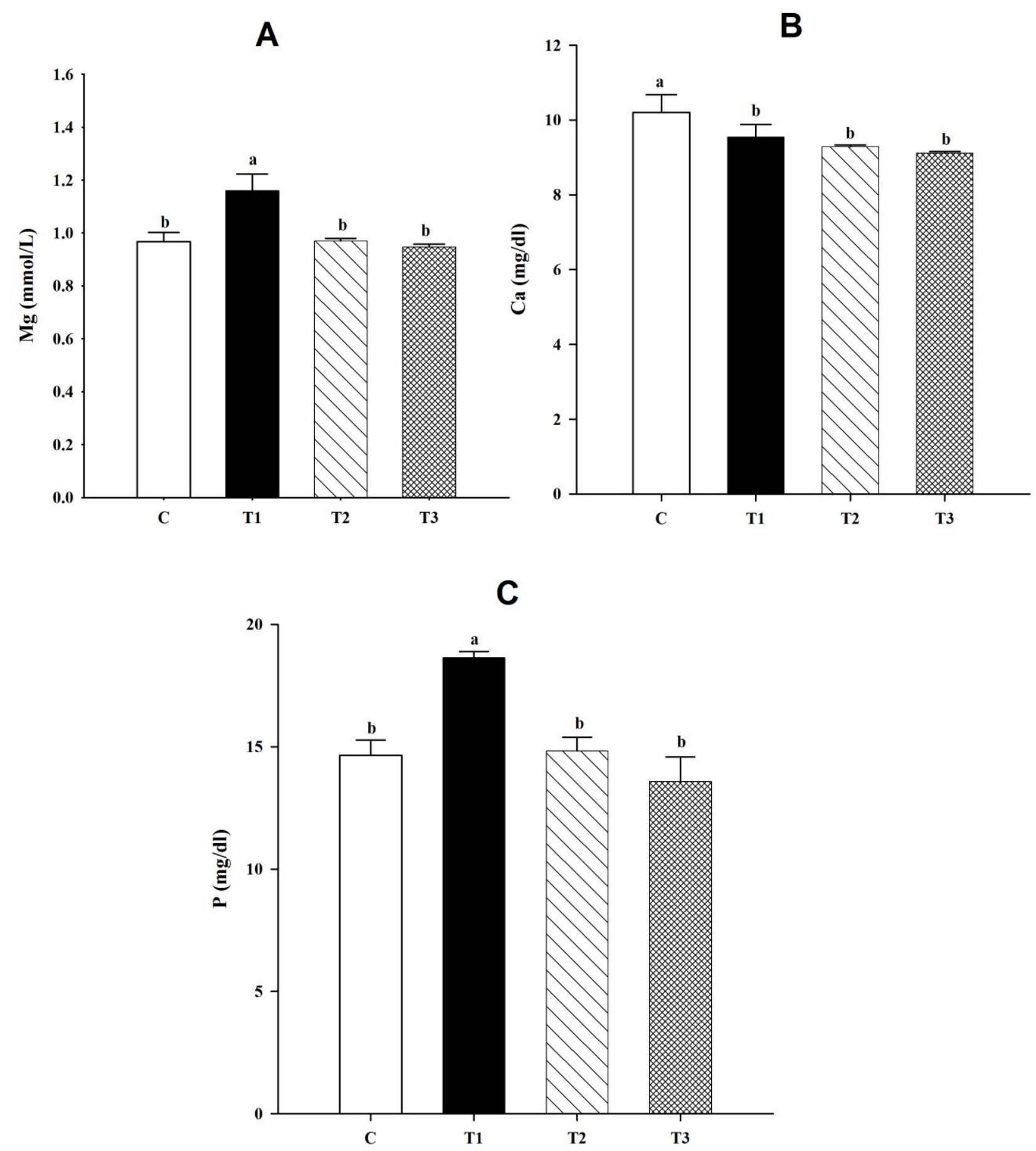

Fig. (1): Blood serum concentration of $\mathrm{Mg}, \mathrm{Ca}$ and $\mathrm{P}$ levels as affected by different treatments 

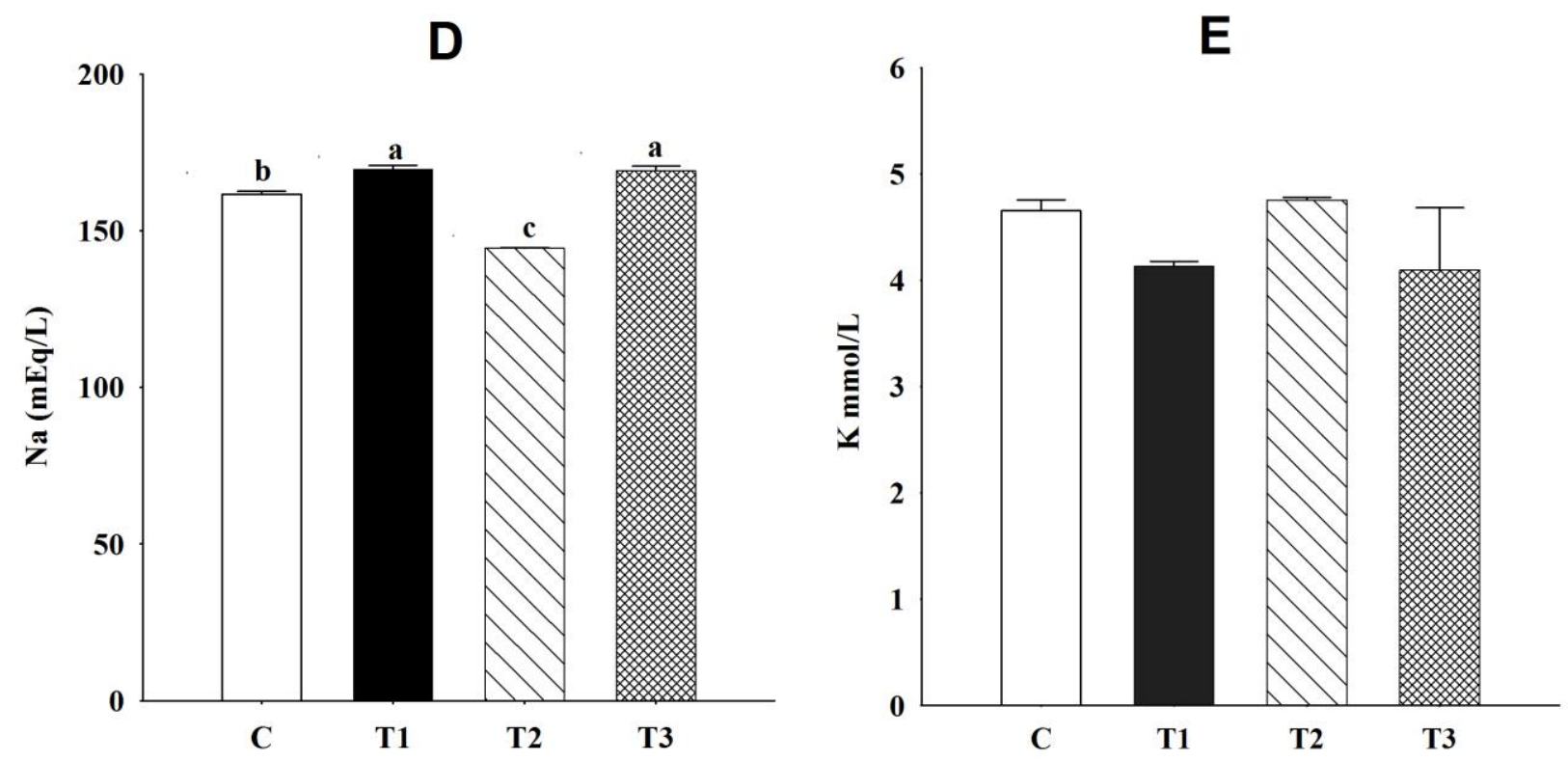

F

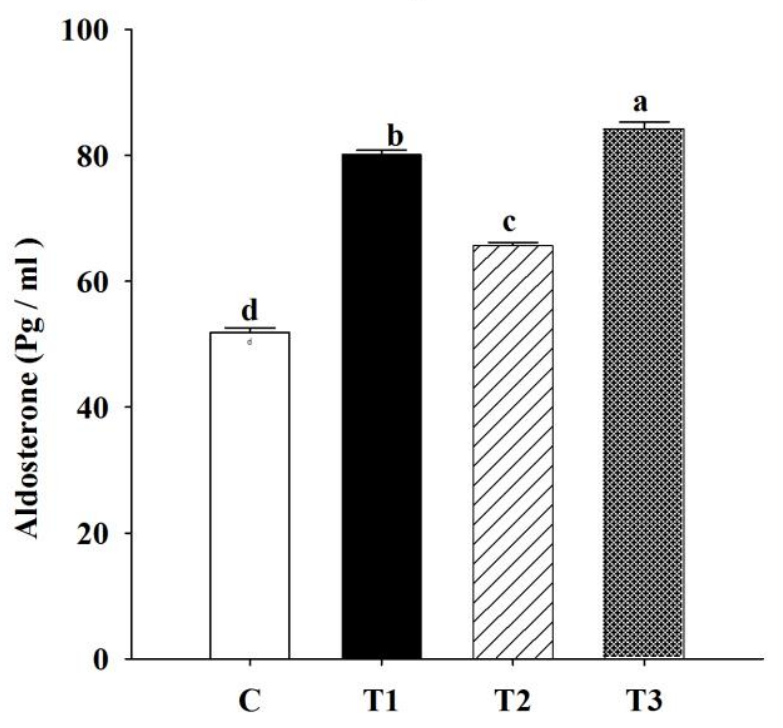

Fig. (2): Blood Na, K and Aldosterone levels as affected by treatments 


\section{REFERENCES}

Afifi, M., Maie, F.A., Abdel-Maksoud, A.M. 1992. Salt stress in broiler chicks: 1. Report: effect of salt stress on some productive traits in broiler chicks. Archiv geflugelkunde. 56: 124-128.

Austic, R. E. 1985. Development and adaptation of protein digestion. Journal of Nutrition: $686-697$.

Balanave , D .1988. The response of Broilers to Sodium Chloride in Drinking Water Proceedings of the Poultry Resear Foundation 1988 Symposium.

Balnave, D.1989. Minerals in drinking water and poultry production. Monsanto Nutrition Update; 7: 1-8.

Changlong Hu, Craig G. Rusin, Zhiyong Tan, Nick A. Guagliardo, and Paula Q. Barrett, 2012. Zona glomerulosa cells of the mouse adrenal cortex are intrinsic electrical oscillators. The Journal of Clinical Investigation http://www.jci.org Volume 122: 20462053.

Damron, B.L. 1998 Sodium chloride concentration in drinking water and eggshell quality. Poultry Sci.; 77: 14881491.

Franchini, A., M. Canti, G. Manfreda, S. Bertuzzi, G. As- drubali and C. Franciosi, 1991 Vitamin E as Adjuvant in Emulsified Vaccine for Chicks," Poultry Science, Vol. 70, No. 8, , pp. 1709-1715.

Gene .M .Pesti, Hector Cervantes , Remzii .Bakalli ,K.W .Bafundo, and M.N.Garcia Khalafalla, M.K., Bessei, W. and Schwarzenberg, A. 1998. Effect of mineral salts in drinking water on the domestic chicken performance a literature review. Archiv. Gefluegelk.; 62: 6-32.

Lawrence G Palmer and Gustavo Frindt 2000. Aldosterone and potassium secretion by the cortical collecting duct. Kidney International 57, 1324-1328.
Lesson , S and J . D Summers 1997. Ingredient Evaluation and Diet Formulation, In Commercial Poultry Nutrition $2^{\text {nd }}$ Ed, pp 101-109 University book.

Marks, H.L 1985. Sexual dimorphism in early feed and water intake of broilers. Poultry Science, v.64, p.425-428.

Meydani, S. N. and J. B. Blumberg 1993.Vitamin $\mathrm{E}$ and the Immune Response," In: S. Cunningham-Rundles, Ed., Nutrient Modulation of the Immune Response, Marcel Dekker, New York, , pp. 223-238.

Murakami, A. E., E. O. O. Rondø'n, E. N. Martins, M. S. Pereira, and C. Scapinello. 2001. Sodium and chloride requirements of growing broiler chickens (twenty-one to forty-two daysof age) fed corn-soybean diets. Poult. Sci. 80:289-294.

National Research Council - NRC 1994. Nutrient requirements of poultry. 8.rev.ed. Washington, D C.: National Academy Press,. 155p.

Ovido-Rondø'n, E. O. O., A. E. Murakami, A. C. Furlan, I. Moreira, and M. Macari. 2001. Sodium and chloride requirements of growing broiler chickens fed corn-soybean diets (one to twenty-one days of age). Poult. Sci. 80:592-598

Ross, E. 1979. The Effect of Water Sodium on the Chic Requirement for Dietary Sodium . Poultry Since 58, 625 - 630.

Shanawany, M.M., Abdel-Rahman, K.M., Akl, M.O 1989. Influence of sodium chloride concentration in drinking-water on shell quality of quail eggs. Proceedings, $3^{\mathrm{Rd}}$ European WPSA Symposium on Egg Quality. Stuttgart, Germany,; 379-383.

Soares, L.F.; Ribeiro, A.M.L.; Penz Jr., A.M. 2007. Influência da restrição hídrica, durante a fase pré-inicial, no desempenho de frangos de corte. Revista Brasileira de Zootecnia, v.5 S, p.15791589 . 
Vena, V. E., T. H. Lac, and R. F. Wideman. 1990. Dietary sodium, glomerular filtration rate. Autorregulation and glomerular size distribution profiles in domestic fowl (Gallus gallus). J.Comp. Physiol. 160:7-16.

Viola, T.H.; Ribeiro, A.M.L.; Penz JR. A.M. 2009. The Influence of Water Restriction on the Performance and
Organ Development of Young Broilers.Revista Brasileira de Zootecnia, v.38, p.323-327.

Watkins . S . E , C . A Firtts , F . Yan, MC . Wilson and P. W. World group 2005. Interaction of Sodium Chloride Levels in Poultry Drinking Water and the Diet of Broilers Chickens Journal of Applied Poultry Research 14 : 55 - 59.

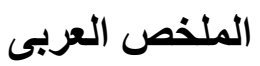

تأثثير مستوى الملوحة والفيتامينات في مياه الشرب على الأداء الإنتاجي وبعض مكونات الدم في دجاج التسمين

$$
\text { قسم الإنتاج الحيواني - كلية الزر اعدة - جمود جامعة جنوب - قنا }
$$

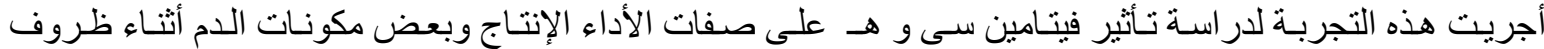

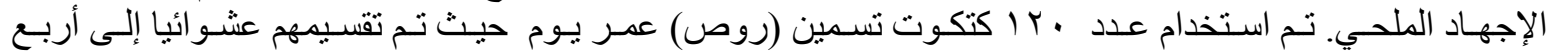

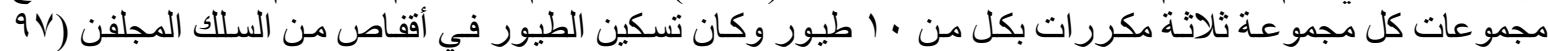

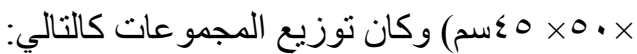

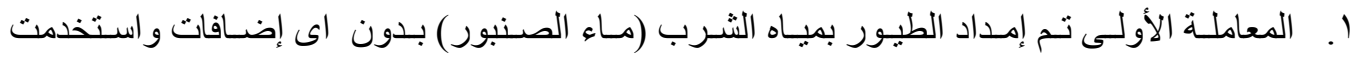

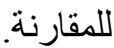

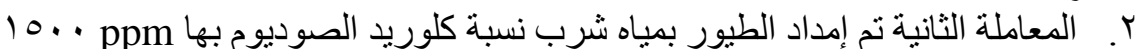

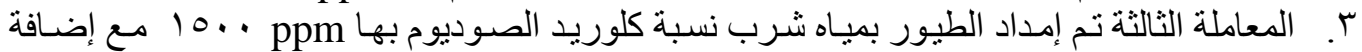
فيتامين E في العليقة بنسبة. ( 100 IU/kg of feed DL- $\alpha$-tocopherol).

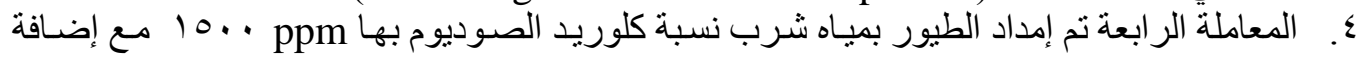

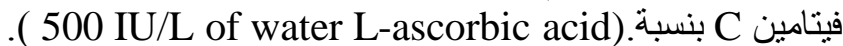

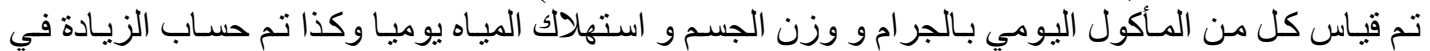

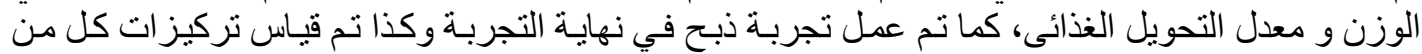

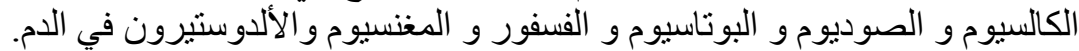

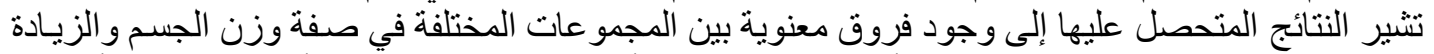

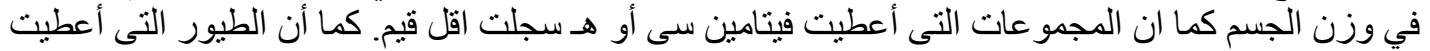

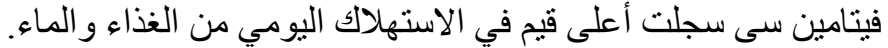

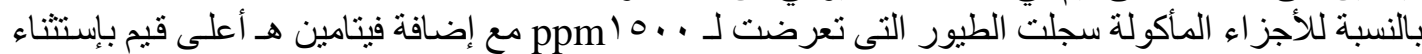

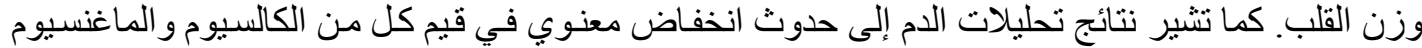

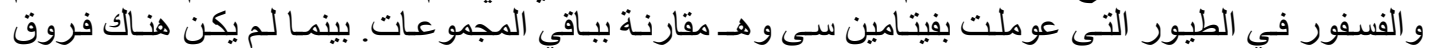

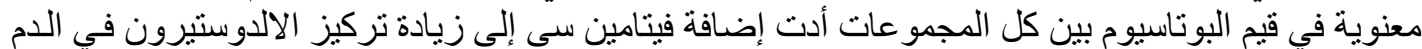

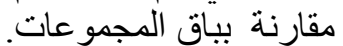

